\title{
Percent Dry Weight of the Ovule Predicts Peach Seed Viability
}

Terry A. Bacon

SunWorld International, LLC, P.O. Box 80298, Bakersfield, CA 93380-9733

David H. Byrne ${ }^{1}$

Department of Horticultural Sciences, Texas A\&M University, College Station, TX 77843-2133

Additional index words. Prunus, nectarine, embryo rescue, germination, breeding

Early season peaches and nectarines [Prunus persica (L.) Batsch] traditionally have relatively high market value, and increasing demand for high quality early season cultivars has made development of these cultivars a high priority for stone fruit breeders. For this reason, breeders are using more early ripening female parent materials in controlled hybridizations. Seeds from early season cultivars, however, are often immature when the fruit is ripe and will not successfully germinate with the normal procedure of stratification for 2 to 3 months in a moist media at $5{ }^{\circ} \mathrm{C}$. Immature seeds that do germinate often grow weakly and die or become stunted with rosetting symptoms.

Many studies have investigated the difficulty of germinating seed of early ripening stone fruit genotypes (Anderson et al., 2002; Connors, 1919; Kester and Hesse, 1955; Ramming, 1990; Tukey, 1933). Early studies found that a peach embryo develops along a sigmoid pattern during which the embryo is visible about $50 \mathrm{~d}$ after full bloom (DAFB), reaches full length (14 to 20 $\mathrm{mm}$ ) about $80 \mathrm{DAFB}$, and finishes accumulating dry matter at about 140 DAFB (Chalmers and van den Ende, 1975; Tukey, 1933).

To germinate and grow strong seedlings from immature seeds, breeders have developed embryo rescue techniques. Today embryo rescue protocols have been developed to an advanced degree and breeders routinely culture embryos as small as $2 \mathrm{~mm}$ in length (Byrne et al., 2000). However, while embryo rescue is a valuable and necessary tool for development of early ripening cultivars, use of traditional stratification-germination is preferable when possible because stratification-germination costs less and requires less labor and equipment. To avoid unnecessary use of embryo rescue, the breeder must be able to accurately assess the embryo maturity status of seed lots to be germinated.

Mostresearch to develop an index of embryo maturity has focused on the improvement of embryo rescue success. Embryo length (mm) and related measurements have been used for many years to determine the degree of embryo development of small embryos (Kester and Hesse, 1955; Ramming, 1990; Theobald and Hough, 1960). Embryo length is not an ideal developmental index because it does not consider the dry weight of the tissue, which is an important developmental indicator (Gage and

Received for publication 26 July 2005. Accepted for publication 9 Sept. 2005.

${ }^{1}$ Corresponding author; e-mail d-byrne@tamu.edu.
Stutte, 1991). Furthermore, peach embryos upon reaching their full length at about $80 \mathrm{~d}$ of age are not yet viable and consequently embryo length has not been a useful tool for determining peach seed viability. Other tools for determining embryo maturity include FDP, embryo dry weight, and percent dry weight of the embryo.

FDP is widely used by breeders as a general index to estimate embryo maturity but FDP is not always known, and even when known embryo maturity with respect to FDP may vary by year and by location. Much of this variability is related to average temperature during fruit development (Boonprakob et al., 1992; Braak, 1978; Gage and Stutte, 1991; Topp and Sherman, 1989). Generally, breeders have found that peach and nectarine embryos with $80 \mathrm{~d}$ FDP or less require embryo rescue for successful germination, and embryos with $>100$ dFDP can be germinated successfully with stratification germination if they are stratified before drying out. However, embryo maturity and germination success varies widely for genotypes with FDP in the 80 - to $100-\mathrm{d}$ range. For these reasons breeders need a more accurate index of embryo maturity than FDP.

Other possible developmental indexes include dry weight of the embryo or seed, and the ratio of embryo dry weight to embryo fresh weight, or percent dry weight of embryo (PDE). PDE has been considered a better indicator of embryo maturity than dry weight alone because seed size is inherently different for different cultivars (Pinto, 1992; Wareing and Phillips, 1981). Pinto (1992) determined that percent dry weight of the ovule (PDO $=$ (ovule dry weight/ovule fresh weight $\times 100)$ is correlated closely with PDE, and it has been shown that most of the dry weight increase of the ovule can be attributed to embryo growth (Chalmers and van den Ende, 1975). In breeding programs PDO would be more efficient than PDE as an index of embryo maturity since the embryo does not need to be extracted from the seed coat in the case of PDO. Therefore, the objective of this study was to determine if PDO reliably estimates embryo maturity as measured by the percent seedling survival from stratification germination.

Fruit and germination data were recorded at College Station, Texas (lat. $30^{\circ} 35^{\prime} \mathrm{N}$, long. $96^{\circ} 21^{\prime} \mathrm{S}$; elevation $96 \mathrm{~m}$ ). The orchards are irrigated and peach trees received uniform cultural practices according to the recommendations for Texas peach orchards (Lyons et al., 1987). Days from full bloom to ripe (FDP) for each genotype was the main developmental index used.Apeach tree was considered in full bloom when $60 \%$ to $80 \%$ of the flowers were open, and the ripe date represents the date of first commercial harvest ( $20 \%$ fruit firm ripe stage). In all genotypes, fruit was gathered when fully mature and stored in a cooler $\left(5^{\circ} \mathrm{C} \pm 2{ }^{\circ} \mathrm{C}\right)$, usually $<1$ week, until fruit could be processed.

Temperature data were based on daily maximum, minimum, and mean temperatures recorded at the Easterwood Airport in College Station (600 $\mathrm{m}$ from the orchard site) and made available by the Texas State Climatologist's Office. The daily thermal time was calculated using a base temperature of $4.5^{\circ} \mathrm{C}$ (degree days $=$ (maximum temperature + minimum temperature) $/ 2-4.5$ ). These were summed for the time period of interest.

A sample of five fruit was taken at the time of harvest from each lot to measure ovule fresh weight (OFW) and ovule dry weight (ODW). OFW (average milligrams per seed) was determined by cracking the pits, then removing and immediately weighing the ovules (seed with testa). The sample was next placed in a drying oven at $37{ }^{\circ} \mathrm{C}$ for $3 \mathrm{~d}$ before removing and weighing to determine ODW (average milligrams per seed). Average percent dry weight (PDO) for each sample was calculated by $($ ODW/OFW $) \times 100$.

Ovules (average of 70 per genotype) were extracted by cracking the endocarp using a Manaresi anvil-type pruner, then ovules were removed and placed immediately into Ziploc brand resealable bags $(26.8 \times 27.9 \mathrm{~cm})$ filled about $500 \mathrm{~mL}$ with moist, washed perlite (ratio $=1$ water $: 6$ perlite) for each 50 seed. Captan fungicide was mixed into the water $\left(2.4 \mathrm{~g} \cdot \mathrm{L}^{-1}\right)$ before mixing with the perlite. The seed lots were kept in a cooler at $5{ }^{\circ} \mathrm{C} \pm 2{ }^{\circ} \mathrm{C}$ until $>75 \%$ of unrotted seeds had emerging radicles ( 2 to 3 months). The seed was then planted into containers in a greenhouse maintained at $29^{\circ} \mathrm{C} \pm 3{ }^{\circ} \mathrm{C}$ (day) and $21{ }^{\circ} \mathrm{C} \pm 3{ }^{\circ} \mathrm{C}$ (night). Because of the differences in ripening time and period required for germination, planting time extended from September through October. Surviving and rosetted seedlings for each seed lot were counted when $>50 \%$ of the surviving normal (non rosetted) seedlings had grown at least $15 \mathrm{~cm}$ (2-3 months) and percent survival (PCTS) of seedlings was calculated: (number survived/number stratified) $\times 100$.

In total, 170 seed lots, representing a range of 59 to $167 \mathrm{~d}$ FDP $($ mean $=97 \mathrm{~d}), 12 \%$ to $76 \%$ PDO (mean $=34 \%$ ) and a range of chilling requirement (150 to 750 chilling units), were selected over 5 years (1994-98) to determine how well FDP and PDO predicted PCTS. This study was designed to represent the actual breeding program environment by using actual breeding germplasm over several years. Although most of the seed lots were from breeding materials, the following cultivars were also in the dataset: 'Dixiland', 'EarliGrande', 'Fireprince', 'Flavorcrest', 'Flordaprince', 'Flordaking', 'Harvester', 'Hawthorne', 'June Gold', 'Juneprince', 'La Feliciana', 'Summerprince', 'TexKing', 'Texprince', and 'TexRoyal'. Data were taken for several years to minimize the possible effects that any particular year would have.

Correlation analysis was done to quantify 
the relationships of PCTS with PDO, FDP, and degree days during FDP (DDFDP), and the PCTS means for each PDO were separated by Duncan's multiple range test ( $5 \%$ level). A

Table 1. Pearson correlation coefficients $(r)^{\mathrm{z}}$ of percent dry weight of ovule (PDO) and fruit development period (days) (FDP) with percent survival of seedlings (PCTS), FDP, and degree days during FDP (DDFDP) $\left(4.5^{\circ} \mathrm{C}\right.$ minimum). Data were taken from 170 seed lots over 5 years at College Station, Texas.

\begin{tabular}{lccc}
\hline Parameter & $\begin{array}{c}\text { PDO } \\
(\%)\end{array}$ & $\begin{array}{c}\text { FDP } \\
\text { (d) }\end{array}$ & $\begin{array}{c}\text { Mean } \\
\text { value }\end{array}$ \\
\hline PCTS (\%) & 0.85 & 0.75 & 47 \\
FDP (d) & 0.86 & & 97 \\
DDFDP & 0.88 & 0.93 & 1629 \\
\hline
\end{tabular}

${ }^{2}$ Correlation coefficients listed are significant at $p=0.05$.

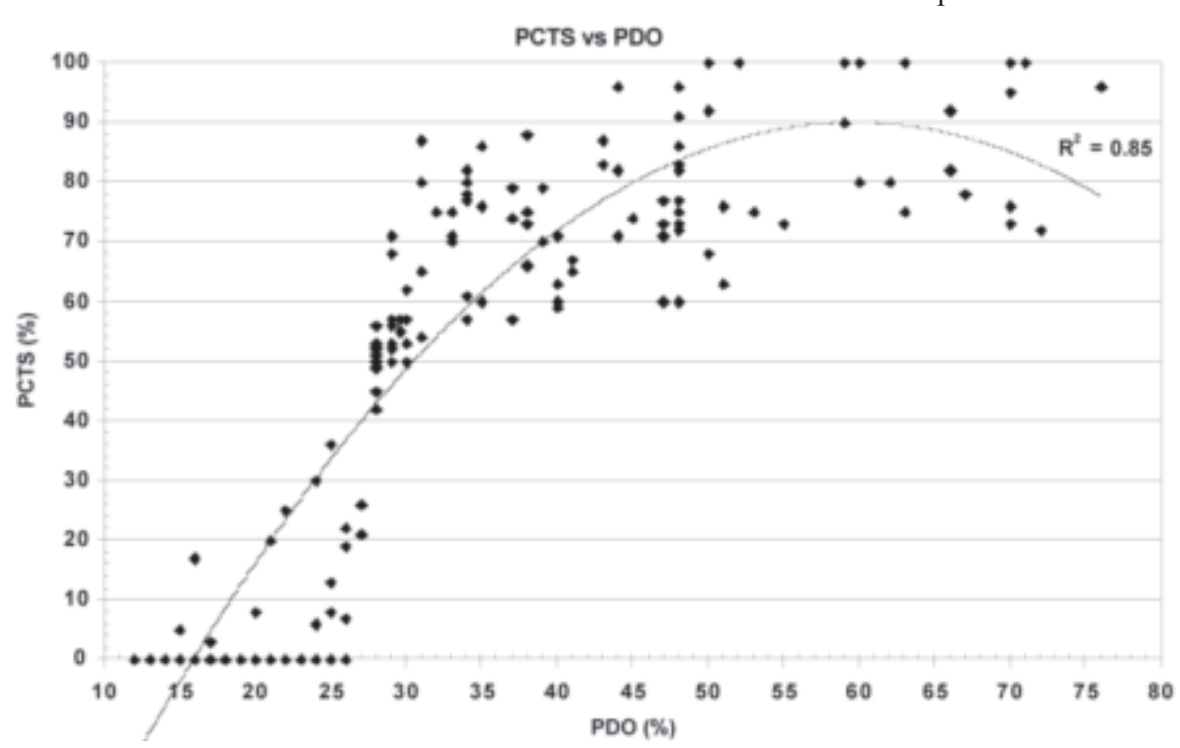

Fig. 1. Regression of percent dry weight of ovule (PDO) and percent survival of seedlings (PCTS) from stratification-germination of breeding population genotypes at College Station, Texas, over 5 years.

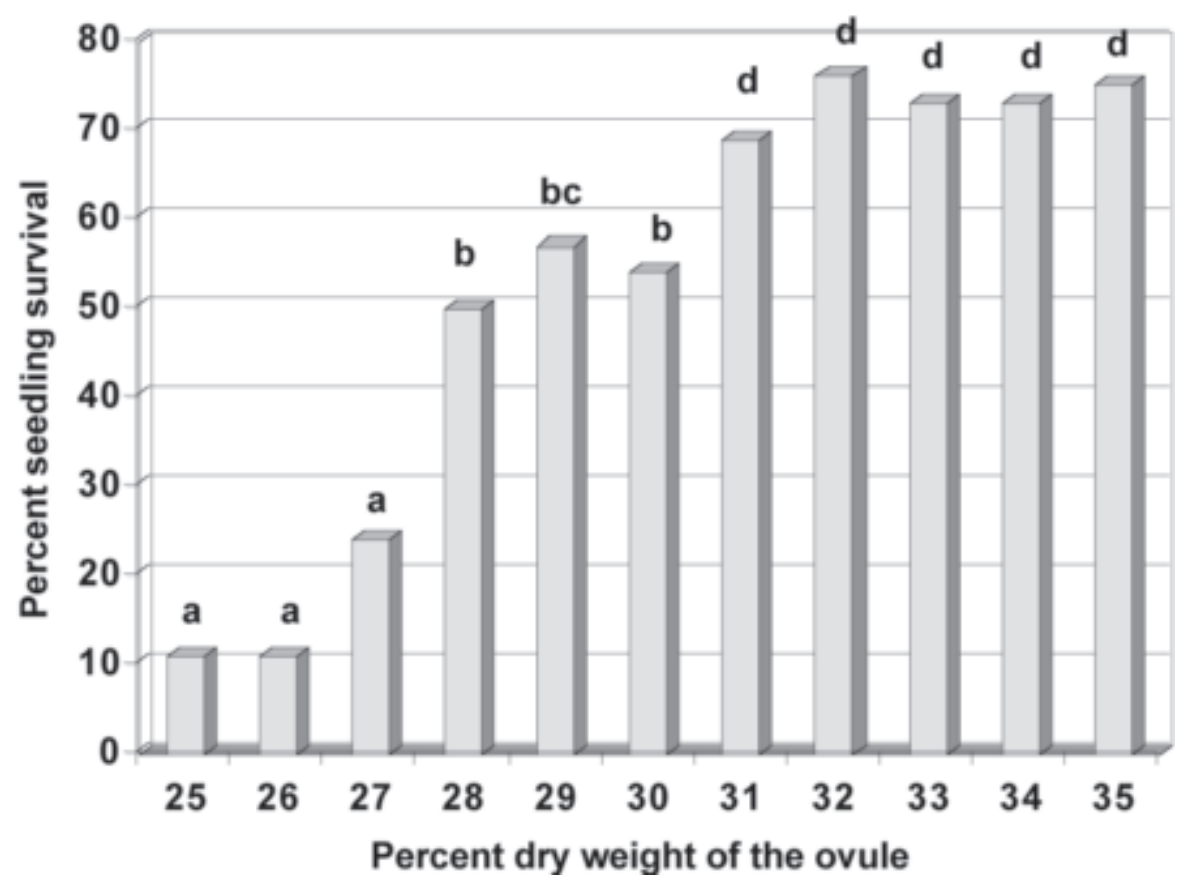

Fig. 2. Average percent seedling survival (PCTS) at varying percent dry weights of the ovule (PDO). Data on these 55 seed lots were taken in College Station, Texas, over 5 years. Means with different letters are significantly different at the $5 \%$ level as determined by the Duncan's multiple range test. at a PDO of $28 \%$. Seed lots with a PDO of less than $28 \%$ had very poor PCTS, but PCTS increased markedly at a PDO of $28 \%$ and was relatively stable at PDO $>30 \%$, averaging $72 \%$ PCTS for this group (Figs. 1 and 2).

Overall it was determined that PDO (calculated with a five-seed sample) in the range of $28 \%$ to $30 \%$ resulted in PCTS of $50 \%$ to $55 \%$, and PDO $>30 \%$ was acceptable for predicting that seed lots would have PCTS $>70 \%$ from stratification-germination. Breeding programs, however, may not always be willing to sacrifice hybrid seed if the seed lot is small. The decision whether to use stratification may be made without sacrificing seed, using a combination ofFDP and mean maximum temperature during FDP (if the information is known), otherwise embryo rescue may be the safest strategy in this instance. Additional studies are needed to develop a reliable maturity index that can measure PDO nondestructively.

\section{Literature Cited}

Anderson, N. D.H. Byrne, J. Sinclair, and A.M. Burrell. 2002. Cooler temperatures during germination improves survival of embryo cultured peach seed. HortScience 37:402-403.

Boonprakob, U., D.H. Byrne, and R.E. Rouse. 1992. Response of fruit development period to temperature during specific periods after full bloom in peach. Fruit Var. J. 46:137-140.

Braak, J.P. 1978. The effect of flowering date and temperature on embryo development in sweet cherry (Prunus avium L.). Neth. J. Agr. Sci. 26:13-30.

Byrne, D.H., W.B. Sherman, and T.A. Bacon. 2000. Stone fruit genetic pool and its exploitation for growing under warm climatic conditions, p. 157-230. In: A. Erez (ed.). Temperate fruit crops in warm climates. Kluwer Academic Publishers, Dordrecht, The Netherlands.

Centellas-Quezada, A., M.C.B. Raseira, I. Citadin, and J.B. da Silva. 1998. Parametros indicativos de necessidade do uso de embriocultura em cultivares precoces de pessegueiro (Prunus persica L. Batsch.). Agropecuaria Clima Temperado 1:55-59.

Chalmers, D.J. and B. van den Ende. 1975. A reappraisal of the growth and development of peach fruit. Austral. J. Plant Physiol. 2:623-634.

Connors, C.H. 1919. Growth of fruits of the peach. N.J. Agr. Expt. Sta. Annu. Rpt. 41:82.

Gage, J. and G. Stutte. 1991. Developmental indices of peach: An anatomical framework. HortScience 26(5):459-463.

Kester, D.E. and C.O. Hesse. 1955. Embryo rescue of peach cultivars in relation to season of ripening. Proc. Amer. Soc. Hort. Sci. 65:265-273.

Lyons, C.G., J. Lipe, and L. Stein. 1987. Orchard establishment, p. 2-11. In: C.G. Lyons (ed.). Texas peach handbook. Texas Agr. Expt. Sta., College Station.

Pinto, A.C. 1992. In vivo and in vitro growth of immature embryos of peach (Prunus persica (L.) Batsch). $\mathrm{PhD}$ diss. Texas A\&M Univ., College Station.

Ramming, D. 1990. The use of embryo rescue in fruit breeding. HortScience 25(4):393-398.

SAS Institute Inc. 1985. SAS user's guide: Statistics. version 5 ed. Cary, N.C.

Theobald, W.L. and L.F. Hough. 1960. The relationship between stages of peach embryo development and seedling growth and survival. Proc. Amer. Soc. Hort. Sci. 75:163-176.

Topp, B.L. and W.B. Sherman. 1989. The relationship of temperature and bloom-to-ripening period in low-chill peach. Fruit Var. J. 43:155-158.

Tukey, H.B. 1933. Growth of peach embryo in relation to growth of fruit and season of ripening. Proc. Amer. Soc. Hort. Sci. 30:209-218.

Wareing, P.F. and I.D.J. Phillips. 1981. Patterns of growth and differentiation in the whole plant, p. 21-45. In: Growth and differentiation in plants. Pergamon, Oxford, U.K 